\title{
Hepatic steatosis associated with microsporidiosis in teleost fishes from Marajó Island, Brazil
}

\author{
MARCELA VIDEIRA ${ }^{1}$, MICHELE VELASCO ${ }^{2}$, PATRÍCIA MATOS ${ }^{3}$, SÉRGIO C. DE SÃO CLEMENTE ${ }^{4}$, \\ OSIMAR SANCHES ${ }^{5}$, PATRÍCIA SANTOS ${ }^{2}$ and EDILSON MATOS ${ }^{2}$ \\ ${ }^{1}$ Laboratório de Morfofisiologia e Sanidade Animal, Universidade do Estado do Amapá/UEAP, \\ Av. Presidente Vargas, 650, Centro, 68900-070 Macapá, AP, Brasil \\ ${ }^{2}$ Laboratório de Pesquisa Carlos Azevedo, Universidade Federal Rural da Amazônia/UFRA, \\ Av. Presidente Tancredo Neves, 2501, Montese, 66077-901 Belém, PA, Brasil \\ ${ }^{3}$ Laboratório de Pesquisa Edilson Matos, Universidade Federal do Pará/UFPA, \\ Rua Augusto Corrêa, 01, Guamá, 66075-110 Belém, PA, Brasil \\ ${ }^{4}$ Faculdade de Veterinária, Universidade Federal Fluminense/UFF, Rua Miguel de Frias, 9, Icaraí, 24220-900 Niterói, RJ, Brasil \\ ${ }^{5}$ Laboratório de Patologia Animal, Universidade do Oeste Paulista/UNOESTE, \\ Rua José Bongiovani, 700, Cidade Universitária, 19050-920 Presidente Prudente, SP, Brasil \\ Manuscript received on April 16, 2013; accepted for publication on November 26, 2013
}

\begin{abstract}
A total of 40 specimens of the teleost fish Gobioides grahamae Palmer \& Wheeler, 1955 were obtained from the municipality of Salvaterra on Marajó Island in the Brazilian state of Pará. Their livers were removed and processed for light microscopy. Overall, $90 \%$ of the specimens presented some degree of steatosis of the liver, which was invariably associated with the presence of Microsporidium sp. The present study confirms the occurrence of steatosis in G. grahamae associated with parasitic infections by Microsporidium. The findings indicate that the condition of otherwise healthy fishes in their natural environment may be affected negatively by parasites.
\end{abstract}

Key words: Marajó Island, Gobioides grahamae, liver, steatosis.

\section{INTRODUCTION}

The vertebrate liver has a number of different functions, in particular the storage of reserves of glycogen and lipids (Bucke et al. 1984). The metabolism of lipids, including the synthesis and degradation of fatty acids, is regulated primarily by the liver, and metabolic imbalances may modify both the morphology and function of the organ, a pathological process known as fatty degeneration or infiltration, steatosis or lipidosis (Coelho 2002, Caballero et al. 2004).

Correspondence to: Edilson Matos

E-mail: edilson.matos9@gmail.com
Morphological modifications, such as the vacuolization of the hepatocytes, glycogen depletion, inflammations, changes in the shape of the sinusoid vessels, and neoplasms may be interpreted as a response to environmental stress or a pathological process caused by infections or parasites (Thomas 1990, Köhler et al. 1992, Teh et al. 1997). Microsporidiosis is caused by microorganisms of the phylum Microsporidia Balbiani, 1882. These organisms exhibit characteristics of both eukaryotes (presence of a nucleus) and prokaryotes (typical ribosomal units), but are included in the Fungi due to their molecular traits (Matos et al. 2003). 
They parasitize organisms of a number of different taxonomic groups, in particular animals, including humans (Polonais et al. 2010, Ghosh et al. 2006, Brasil et al. 1997) and insects (Matos et al. 2006).

Microsporidians may be found in a number of different types of organs, including the liver, kidneys, gills, gonads, intestine, and skin, in which they cause major alterations to the tissue. The present study describes the presence of hepatic steatosis in the teleost fish Gobioides grahamae Palmer \& Wheeler, 1955, associated with parasitic infection by Microsporidium sp.

A total of 40 specimens of $G$. grahamae were examined. The specimens (15 females and 25 males) had a mean standard length of $16 \mathrm{~cm}$ (range: 12-20 $\mathrm{cm}$ ) and mean weight of $70 \mathrm{~g}$ (range: $50-90 \mathrm{~g}$ ), and were collected in the municipality of Salvaterra $\left(00^{\circ} 45^{\prime} 21^{\prime \prime} \mathrm{S}, 48^{\circ} 30^{\prime} 54^{\prime \prime} \mathrm{W}\right)$ on the island of Marajó, in the northern Brazilian state of Pará, between June and December, 2011. The fishes were kept in aerated plastic bags for transportation to the Carlos Azevedo Research Laboratory at UFRA in the capital of the state of Pará, Belém. where they were anesthetized with MS 222 (Sandoz Laboratories), prior to necropsy.

The necropsies on the hosts began with opening the abdominal cavity using a pair of anatomical scissors, in order to gain access to the viscera. The organs were examined under a stereomicroscope.

For light microscopy, small fragments $(0.5$ $\mathrm{cm}$ ) of the liver tissue parasitized by microsporidia were fixed in Davidson's solution (formaldehyde, ascetic acid, 95\% ethanol, and distilled water) for 24 hours and then embedded in paraffin. Sections of $3 \mu \mathrm{m}$ were stained with Masson's trichrome and hematoxylin-eosin (Luna 1968). The stained sections were analyzed and photographed using a Nikon E-200 microscope, with Micrometrics ${ }^{\circledR}$-SE Premium imaging software.

Most (90\% or 36/40) of the specimens examined presented hepatic steatosis, a pathological process associated with infection by Microsporidium sp. Macroscopically, the livers of these specimens were characterized by an increase in volume and yellow blemishes, as described by Coelho (2002). Microscopically, the dislocation of the layers of hepatocytes and a large quantity of adipocytes could be observed in the hepatic stroma. The histopathological analysis revealed modifications of the liver cells, which were disorganized, with signs of accentuated and diffused steatosis, moderate colestasis, and multifocal necrosis.

This study highlights the prevalence of hepatic steatosis higher than that described by Rosenthal et al. (2013), who studied the occurrence of hepatic steatosis in Oncorhynchus mykiss from cultivation, finding that $70.6 \%$ of the fish had lesions consistent with hepatic steatosis.

The hepatic steatosis was characterized by the presence of clear, rounded cytoplasmatic vacuoles, with hepatocytes of increased volume and dislocated nuclei (Figure 1). Cysts of Microsporidium sp. surrounded by leucocytes were also present. Staining with Masson's trichrome revealed the presence of a fine capsule of collagen surrounding the cysts which, in some specimens, had been ruptured, releasing spores into the threads of hepatocytes (Figure 2).

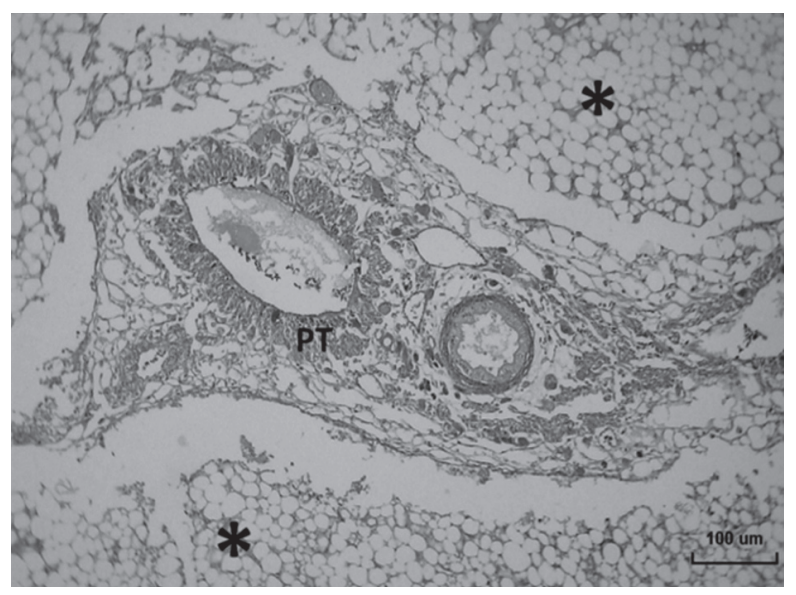

Figure 1 - Gobioides grahamae. Light photomicrograph of a liver specimen, showing the disorganization of the threads of hepatocytes, and the marked intracytoplasmatic vacuolization of the cells $(*)$, which is typical of diffuse steatosis. Note the presence of intra-hepatic pancreatic tissue (PT). Masson's trichrome staining. Scale bar $=100 \mu \mathrm{m}$. 




Figure 2 - Gobioides grahamae. Microsporidium sp. Light photomicrograph showing the dislocated threads of vacuolated hepatocytes, hyaline intracellular deposits (h), and the thickening of the cell membrane of the hepatocytes (small arrows) associated with a Microsporidium sp. cyst (Ci) with a capsule of conjunctive tissue (large arrows) which has ruptured (arrowheads), releasing spores among the hepatocytes (*). Masson's trichrome staining. Scale bar $=100 \mu \mathrm{m}$.

Casal (2009) noted that the spores are the only life phase of Microsporidium sp. that could be observed effectively under light microscopy. The spores are ellipsoid or ovoid in shape, and were the only form of the parasite observed in the specimens analyzed in the present study. No microsporidian spores were found in the specimens without steatosis, indicating that the presence of the parasite is the factor determining the occurrence of this disorder in G. grahamae.

Diseases of the liver include infectious conditions, such as those caused by fungi (as in the present study, associated with microsporidian cysts), bacteria, viruses, and protozoans, and noninfectious disorders, all of which are generally characterized by lesions and an increase in the volume of the liver, which is easily observed macroscopically. Francisco (2006) and Campos et al. (2008) observed steatosis in fishes maintained in contaminated environments, although Thomas (1990), Silva (2004), Santos et al. (2004), and Camargo and Martinez (2007) found no lesions whatsoever, even in polluted environments.
It is important to note that the release of toxins by microorganisms - in the present case, related to the presence of Microsporidium sp. - is one of the main causes of steatosis, due to the fact that it reduces the production of proteins by the rugose endoplasmatic reticulum, which has a direct effect on the metabolism of lipids by the hepatocytes (McGavin and Zachary 2007). The present study found that the condition of otherwise healthy fishes in their natural environment may suffer adverse effects from parasitism.

\section{ACKNOWLEDGMENTS}

We are grateful to The Edilson Matos Research Laboratory (LPEM-UFPA), Dr. Stephen Ferrari for the translation and revision of the manuscript, Coordenação de Aperfeiçoamento de Pessoal de Nível Superior (CAPES), Conselho Nacional de Desenvolvimento Científico e Tecnológico (CNPq, universal research program) and Fundação Amazônia Paraense de Amparo à Pesquisa (FAPESPA).

\section{RESUMO}

Um total de 40 exemplares do peixe teleósteo Gobioides grahamae Palmer \& Wheeler, 1955 foram obtidos a partir do município de Salvaterra na Ilha de Marajó, no estado brasileiro do Pará. Os fígados foram removidos e processados para a microscopia de luz. De modo geral, 90\% das amostras apresentavam algum grau de esteatose hepática, a qual foi invariavelmente associada com a presença de Microsporidium sp. O presente estudo confirma a ocorrência de esteatose em G. grahamae associada a infecções parasitárias por Microsporidium. Os resultados indicam que as condições de peixes saudáveis em ambiente natural podem ser afetadas negativamente por parasitas.

Palavras-chave: Ilha do Marajó, Gobioides grahamae, fígado, esteatose.

\section{REFERENCES}

BRASIL P, BONFIM DE LIMA D AND MOURA H. 1997. Microsporidiose humana na síndrome de imunodeficiência adquirida. Rev Ass Med Bras 43(3): 254-264. 
Bucke D, Watermann B And FeIST S. 1984. Histological variations of hepato-splenic organs from the North Sea dab, Limanda limanda (L.). J Fish Dis 7: 255-268.

CABALlero MJ, IzQUiERdo MS, KJøRSVIK E, FERnANDEZ AJ AND RosenLUND G. 2004. Histological alterations in the liver of sea bream, Sparus aurata L., caused by shortor long-term feeding with vegetable oils. Recovery of normal morphology after feeding fish oils the sole lipid source. J Fish Dis 27: 531-541.

CAMARGo MMP AND MARTinez CBR. 2007. Histopathology of gills, kidney and liver of a Neotropical fish caged in an urban stream. Neotrop Ichthyol 5(3): 327-336.

CAmpos CM, Moraes JRE AND Moraes FR. 2008. Histopatologia de fígado, rim e baço de Piaractus mesopotamicus, Prochilodus lineatus e Pseudoplatystoma fasciatum parasitados por myxosporídios, capturados no Rio Aquidauna, Mato Grosso do Sul, Brasil. Rev Bras Paras Vet 17(4): 200-205.

CASAL G. 2009. Microsporidioses e Mixosporidioses da ictiofauna portuguesa e brasileira: Caracterização ultraestrutural e filogenética. Tese (Doutorado em Ciências Biomédicas). Porto-Portugal. Instituto de Ciências Biomédicas Abel Salazar, Universidade do Porto, 249 p.

CoElHo HE. 2002. Patologia veterinária. São Paulo: Manole, p. 234.

FRANCISCO CJ. 2006. Fauna parasitária e alterações teciduais em peixes oriundos de pisciculturas com mono ou policultivo do médio vale do Itajaí, SC. Dissertação (Mestrado em Aquicultura). Centro de Aquicultura da Universidade Estadual Paulista, Jaboticabal, 49 p. (Unpublished).

Ghosh K, Cappiello CD, McBride SM, Occi JL, Cali A, TAKVORIAN PM, MCDONALD TV AND WEISS LM. 2006. Functional characterization of a putative aquaporin from Encephalitozoon cuniculi, a microsporidia pathogenic to humans. Int J Parasitol 36: 57-62.

Kohler A, Deisemann H And Lauritzen B. 1992. Histological and cytochemical indices of toxic injury in the liver of dab Limanda limanda. Mar Ecol Prog Ser 91: 141-153.

LUNA LG. 1968. Manual of histologic staining methods of the Armed Forces Institute of pathology. $3^{\text {rd }}$ ed., American Registry of Pathology, Edition, 258 p.
Matos E, Matos P, Casal G, Giese E, Corral L and AzEvedo C. 2003. Dados ultra-estruturais de esporos de microsporídios (Phylum Microsporidia) da fauna ictiológica da Região Amazônica. Rev Cienc Agrár 39: 95-108.

Matos E, MendonçA I AND AzeVEdo C. 2006. Vavraia lutzomyiae n. sp. (Phylum Microspora) infecting the sandfly Lutzomyia longipalpis (Psychodidae, Phlebotominae), a vector of human visceral leishmaniasis. Eur J Protistol 42: 21-28.

McGaVIn MD AND ZaCHARY JF. 2007. Pathologic Basis of Veterinary Disease. Mosby Elsevier. St Louis, $4^{\text {th }}$ ed., p. 39-40.

Polonais V, Mazet M, WaWrzyniak I, Texier C, Blot N, El Alaoui H and Delbac F. 2010. The Human Microsporidian Encephalitozoon hellem Synthesizes Two Spore Wall Polymorphic Proteins Useful for Epidemiological Studies. Infect Immun 78(5): 2221-2230.

Rosenthal NS, SANDOVAL CN, GAVIDIA CC AND TABACCHI NL. 2013. Frequency of hepatic lipidosis in juvenile rainbow trout (Oncorhynchus mykiss) in a fish farm in the Peruvian central Sierra. Revista de Investigaciones Veterinarias del Perú 24(1): 118-124.

SANTOS AA, RANZANI-PAIVA MJT, FELIZARDo NN AND RODRIGUES EL. 2004. Análise histopatológica de fígado de tilápia-do-Nilo, Oreochromis niloticus, criada em tanque-rede na represa de Guarapiranga, São Paulo, SP, Brasil. Bol Inst Pesca 30(2): 141-145.

SILVA AG. 2004. Alterações histopatológicas de peixes como biomarcadores de contaminação aquática. Dissertação (Mestrado em Ciências Biológicas), Universidade Estadual de Londrina, Paraná, 74 p. (Unpublished).

TeH SJ, AdAms SM AND HINTON DE. 1997. Histopathological biomarkers in feral freshwater fish populations exposed to different types of contaminant stress. Aquat Toxicol 37: 51-70.

ThOMAS P. 1990. Molecular and biochemical responses of fish to atressors and their potential use in environmental monitoring. American Fisheries Society Symposium Bethesda 8: 9-28. 